\title{
Determination of vertical dimension using intercanthal distance in adult Mongoloid race
}

\author{
Law Kam Yaw, Gantini Subrata, Rachman Ardan \\ Department of Prosthodontic Faculty of Dentistry Universitas Padjadjaran
}

\begin{abstract}
Objective methods of determining the vertical dimension of occlusion (VDO) offer significant advantages because no radiographs or others special measuring devices are required. One of the objective measurement of vertical dimension of occusion is twice the intercanthal distance (ICD). The purpose of this study was to compare whether there was a difference between the length of VDO and the length of twice the ICD among Mongoloid race, which was represented by eighty students, chosen randomly from undergraduate students of Faculty of Dentistry Universitas Padjadjaran that fulfilled all criteria stated. Result showed that there was no difference between the length of VDO and twice the ICD in this population. Thus, in this study, the ICD can be suggested as a method to determine the VDO in this population.
\end{abstract}

Key words: Vertical dimension of occlusion, intercanthal distance, Mongoloid race

\section{ABSTRAK}

Metode objektif untuk menentukan VDO menawarkan keuntungan karena tidak perlu memakai radiografi atau alat pengukur khusus lainnya. Salah satu metode pengukuran objektif VDO adalah dua kali jarak intercanthal (ICD). Tujuan penelitian ini untuk mengetahui apakah terdapat perbedaan antara ukuran VDO dengan dua kali jarak IC) pada ras Mongoloid yang diwakili oleh mahasiswa /i S1 Fakultas Kedokteran Gigi Universitas Padjadjaran yang memenuh kriteria, dipilih secara acak. Hasil penelitian menunjukkan tidak terdapat perbedaan antara ukuran VDO dengan dua kali jarak ICD pada populasi ini, jadi ukuran ICD dapat disarankan untuk dipakai sebagai metode objektif dalam menentuan ukuran VDO pada populasi ini.

Kata kunci: Dimensi vertikal oklusi, jarak intercanthal, ras Mongoloid 


\section{INTRODUCTION}

Among the most complex restorative challenge for a dentist is that related to determine vertical dimension of occlusion (VDO). ${ }^{1}$ The methods for determining the vertical maxillomandibular relations can be grouped roughly into two categories. The mechanical (objective) group of method includes the use of pre-extraction records (profile radiographs, casts of teeth in occlusion, and facial measurements), measurement of former dentures and ridge relation. The physiologic (subjective) group of method includes the measurement of the physiologic rest position, phonetics, swallowing phenomenon, and tactile sense. ${ }^{2}$ The subjective methods are used most frequently to determine the VDO. However, there are not completely accurate methods of determining VDO in edentulous patients. ${ }^{3}$

Objective methods of determining the VDO were proposed to be used because it offers significant prosthetic advantages. The facial and finger measurements are attractive because they required no radiographs or others special measuring devices. According to $\mathrm{Misch}^{4}$, the original VDO Was most often similar to at least 12 other dimensions on the face and hands and may be objectively determined in most patients. One of the dimensions is twice the distance between the inner canthus of both eyes. ${ }^{4}$ Study done by Ebadian and Hedayatresa to evaluate the ability of anthropometry as a new method of determining the VDO concluded that some guidelines could be used in determination of the VDO using anthropometry. ${ }^{5}$

The anatomical point of the inner canthus of both eyes is fixed thus it is easy to determine the intercanthal distance (ICD). Moreover, the measurement of the ICD is the exact measurement compared to other such as distance between the hairline and eyebrows in which the anatomy point is hard to determine. All the measurements of $\mathrm{Misch}^{4}$ were possibly done in United States which is mostly represented by Caucasian people and his suggestion may be true for Caucasoid race. There is a variety of differences between the Caucasoid race and the Mongoloid race, such as skin color, facial profile and stature. ${ }^{6}$ However, there is still no data found using the length of twice the ICD to determine VDO on Mongoloid race.
Beside of the racial differences, there is variation between male and female. The study conducted by Oladipo et al. ${ }^{7}$ on Nigeria about the craniofacial dimensions of Ijaw Children and adolescents revealed that the mean values for all the parameters of facial measurements were significantly higher in male than in female subjects $(P<0.05)$, with exception of nasal height. ${ }^{7}$

The purpose of this study was to compare whether there were any difference between the length of VDO and the length of twice the intercanthal distance (ICD) among Mongoloid race.

\section{MATERIALS AND METHODS}

Twenty five male and 55 female students who fulfill the criteria below were studied: Mongoloid or mongoloid subrace at least 2 generation above; Undergraduate student of Faculty of Dentistry, Universitas Padjadjaran, batch 2006, 2007 and 2008; Normal Body Mass Index (BMI) 18.5-24.98; No obvious facial deformities; No extensive caries, attrition, abrasion, clinical crown wear on the whole occlusal surface of teeth examined visually ${ }^{9}$; No tooth mobility ${ }^{10}$; Angle's Class I molar relationship with normal overbite and overjet ${ }^{11}$; No previous history of tooth extraction or tooth lost on all teeth excluding the third molars'; Not previous or currently undergoing orthodontic treatment; and No temporomandibular joint disorders (TMD). ${ }^{12}$

The two parameters, ICD and VDO were measured with digital vernier caliper having a resolution of $0.01 \mathrm{~mm}$. The ICD was measured from the medial angle to the medial angle of the palpebral fissures of both eyes (Fig. 1). VDO was measured from Subnasion (Sn) and Gnathion (Gn) points (Fig. 2). Each parameter was measured three times and the average value was recorded. The mean value of ICD of the sample was multiply by two in order to obtained the value of twice the ICD of both eyes.

The data obtained was subjected to statistical analysis by using SPSS program. The type of statistical analysis used to test the data of mean length of VDO and twice the ICD was Student's ttest. While Pearson Correlation test or also known as Product Moment Correlation test was used to test whether there was any relationship between 
the mean length of VDO and twice the ICD. ${ }^{13}$ Beside total sample measurements, the different of male and female in the length of VDO and twice the ICD were study too.

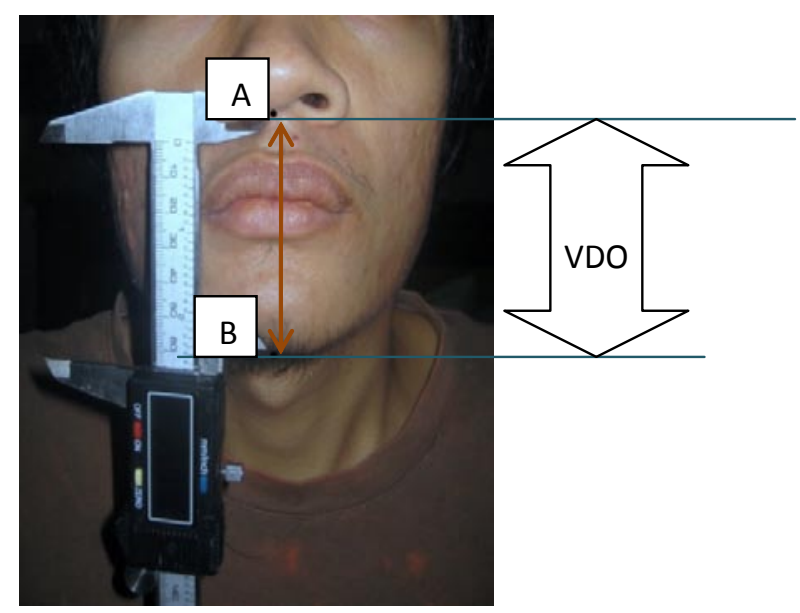

Figure $1 \mathrm{~A}$. Subnasion and B. Gnathion were marked with an ink pen and measure with digital vernier caliper.

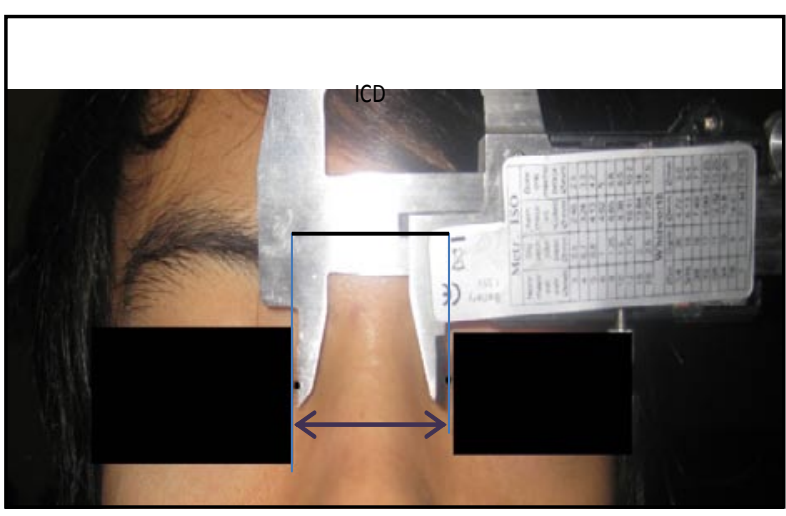

Figure 2. Measurement procedure of ICD by using digital vernier caliper.

\section{RESULTS}

The means of measurements obtained are shown in Diagram 1 and 2. The mean length of VDO was 63.99 while the mean length of twice the ICD was 64.33. The mean length of VDO in male and female was 68.11 and 61.54 respectively. The mean length of twice the ICD in male and female was 68.26 and 62.24 respectively,

Result of statistical calculations showed that there was no difference between the mean length of VDO and twice the ICD. There were correlation between the mean length of VDO and twice the ICD.

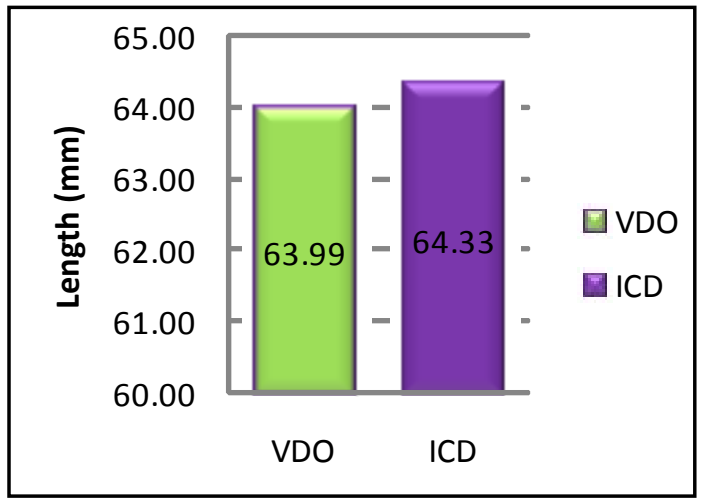

Diagram 1. Comparisons of the mean length of VDO and twice ICD.

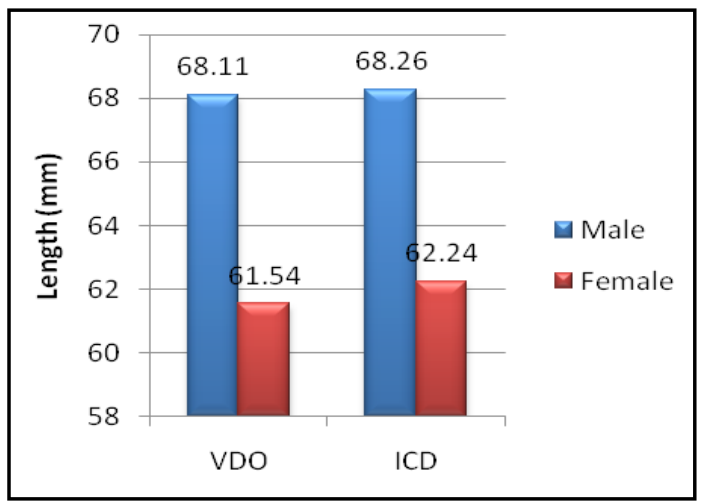

Diagram 2. Differences between male and female in the mean length of VDO and twice ICD.

Result of statistical calculations also showed that there was difference between male and female samples in the mean length of VDO and mean length of twice the ICD examined in this study.

\section{DISCUSSION}

Theresultsshowed that thereweresignificant differences in the mean length of VDO and twice the ICD between male and female samples. This finding is consistent with the research done by Oladipo et al. ${ }^{8}$ In his research, he revealed that the mean values for all the parameters of facial measurements were significantly higher in male than in female subjects $(P<0.05)$, with exception of nasal height. This difference can be because of facial dimensions were modified during growth and development with sex-related characteristics. ${ }^{8}$ Individual variation across the example of male and female encompass a range of features; for 
example, clear differences are found in the length and width of the nose and mouth, the inclinations of forehead and nose, as well as the overall shape of the face. ${ }^{14}$

After subjected to hypothesis testing, the results showed that there were no significant differences in the mean length of VDO and twice the ICD as a whole and in both male and female samples. This finding is consistent with the findings of Misch in which he stated that the original VDO was most often similar to at least 12 other dimensions on the face and hands and may be objectively determined in most patients. One of the dimensions is twice the distance between the inner canthus of both eyes. Although there are many differences between male and female, the proportion of one body part to another body part in one individual is the same for both sex groups. ${ }^{15}$

Lastly, when subjected to Pearson Correlation test there was a variation of results in female samples. This may be because within female, there was a layer of subcutaneous fat develops which causes the rounding and softening the contours of the face and body. Whereas, the male subcutaneous fat development was much less pronounced due to the effects of testosterone which reduces fat by aiding fast metabolism. This gives the male a leaner and more angular face than the female. ${ }^{16}$ Even though, there was a variation in female samples, there was still a relation between the length of VDO and twice the ICD. May be due to this variation, the total correlation coefficient of the length of VDO and twice the ICD is lower than the expectation.

Previous reveal by Misch, were possibly done in United States which is mostly represented by Caucasian people who belong to the Caucasoid race. According to Misch, the original VDO is most often similar to twice the distance between the inner canthus of both eyes. On the contrary, this research was conducted among the undergraduate Mongoloid students of Faculty of Dentistry in UNPAD who belong to Mongoloid race. This research proven that even in Mongoloid study samples there was correlation between mean length of VDO and twice the ICD which was similar to Misch finding among the Caucasoid research samples even though the correlation is only 0.722 . Anthropometric studies in health North American
Caucasians and Chinese populations discovered a variety of proportional relationships in the face. ${ }^{17}$

\section{CONCLUSION}

There was no difference between the mean length of VDO and twice the ICD. Therefore, the length of twice the ICD can be recommended to be used as one of the guide in the determination of VDO when the patient's VDO is already lost in this population. However, other methods of determination of VDO should be used together in order to obtain a more accurate measurement.

\section{REFERENCES}

1. Guertin G. The evaluation of occlusal vertical dimension. J Dent du Québec 2003;40:241-3.

2. Boucher CO. Prosthodontic treatment for edentulous patients. $9^{\text {th }}$ ed. St. Louis: The C.V. Mosby Co; 1985. p. 270.

3. Kharat DU. A method for correction of increased vertical dimension in complete dentures. Saudi Dent J 1989;1(3):78-81.

4. Misch CE. Objective vs subjective methods for determining vertical dimension of occlusion. Quintessence Int.; 2000;31(4):280-2.

5. Ebadian B, Hedayatresa F. Assessment of vertical dimension of occlusion using anthropometry. Dent J 2003:82-91.

6. Siegel JA, Knupfer GC, Saukko PJ. Encyclopedia of forensic sciences, $4^{\text {th }}$ ed. set. Elsevier; 2000. p. 1077-84.

7. Oladipo GS. Esomonu E, Osogba IG. Craniofacial dimensions of jaw children and adolescents in Nigeria. Biomedic Int. (2010)1:25-9.

8. Ferrario VF, Dellavia C, Tartaglia, Turci M, Sforza C. Soft tissue facial morphology in obese adolescents: A three-dimensional noninvasive assessment. Angle Orthod 2004;74(1):37-42.

9. Zarb GA, Bolender JC, Eckert SE, Jacob RF, Fenton AH, Mericske-Stern R. Prosthodontic treatment for edentulous patients complete dentures and implant-supported Prostheses. $12^{\text {th }}$ ed. Elsevier. 2004. p. 3,268-3.

10. Takei HH, Newman MG, Klokkevold PR, Carranza FA. Carranza's clinical periodontology $10^{\text {th }} \mathrm{ed}$. Saunders Elsevier. 2006. p. 546.

11. Proffit WR, Fields HW, Sarver DM. Comtemporary orthodontics. $4^{\text {th }}$ ed. St. Louis: 
Mosby; 2007. p. 4,11.

12. Dawson PE. Functional occlusion from TMJ to smile design. Mosby Elsevier; 2007. p 114-29.

13. Lind DA, Mason RD, Marchal WG. Basic statistics for business and economics. $3^{\text {rd }} \mathrm{ed}$. McGraw-Hill; 2000. p. 222,301,361.

14. DeCarlo DM. Generation, estimation and tracking of faces. partial fulfillment Requirements for the Degree of Doctor of Philosophy pennsylvania: University of Pennsylvania; 1998. p. 22.

15. Van Der Beek MCJ, Hoeksma JB, Prahl-Andersen $B$. Vertical facial growth and statural growth in girls: a longitudinal comparison. Eur J Orthod 1996;18:549-55.

16. Lewis J. The physiological and psychological development of the adolescent. Adolescence/ adolescents' health Yale-New Haven Teachers Institute. 1991;5:7 [cited 2011 Jan 21]. Available from:www.yale.edu/ynhti/.../1991 /5/91.05.07.x.ht.

17. Dawei W, Guozheng Q, Mingli Z, Farkas LG. Differences in horizontal, neoclassical facial Canons in Chinese (Han) and North American Caucasian populations. Aesth Plast Surg 1997;21:265-9. 